\title{
The Study on the Impact of Liberia's Exports and Imports on Its Economic Growth
}

\author{
Faliku S. Dukuly*, Kun Huang* \\ School of Economics and Management, Shanghai Maritime University, Shanghai, China \\ Email: faliku@stu.shmtu.edu.cn, falikud@gmail.com, huangkun@shmtu.edu.cn
}

How to cite this paper: Dukuly, F. S., \& Huang, K. (2020). The Study on the Impact of Liberia's Exports and Imports on Its Economic Growth. Open Journal of Business and Management, 8, 2649-2670. https://doi.org/10.4236/ojbm.2020.86164

Received: September 5, 2020

Accepted: November 20, 2020

Published: November 23, 2020

Copyright $\odot 2020$ by author(s) and Scientific Research Publishing Inc. This work is licensed under the Creative Commons Attribution International License (CC BY 4.0).

http://creativecommons.org/licenses/by/4.0/

\begin{abstract}
Liberia is labeled at the peak considered as one of the poorest countries in the world. Therefore, Liberia needs to take an effective trade policy approach to promote both domestic and international trade facilitation if it is to achieve sustainable and further economic growth. International trade is the engine for economic development, and it has become one of many economic discussions not only among West African States and member countries but globally that Liberia is no exception to since exports-trade leads to GDP growth and economic development. As a result of frequent trade deficits and Liberia's economic reliance on extractive commodities for trade in agricultural goods, the study sought to analyze the role of exports-trade on economic growth and development with regard to Liberia. The study was conducted using secondary data generated from the World Bank Development Indicators (WBDI) for the period 2000-2019. The study employed a time series regression model of the Ordinary Least Squares (OLS) and technique by Stock and Wilson (1988) to analyze Liberia's trade performance using macroeconomic indicators/variables that have an effect on economic growth, such as, Exports, Foreign Direct Investment (FDI), Population growth, Imports, Gross Fixed Capital Formation, (GFCF) and Gross Domestic Product (GDP) as the key indicators of analysis. The regression results obtained from the study on the Ordinary Least Squares tests show a linear association and a straight-line relationship among the variables, namely: export, foreign direct investment, population and economic growth in Liberia. With the estimated results, import has a negative impact and relationship with Liberia's GDP growth. The effect of export was positive and highly statistically significant.
\end{abstract}

\section{Keywords}

Liberia, Economic Growth, Exports, Export-Led Growth, Imports, International Trade

*Faliku S. Dukuly: M. Econs; Kun Huang: Ph.D. 


\section{Introduction}

In West Africa, along the Coast is Liberia. Founded in 1847, Liberia is the oldest African Republic with a current population of 5,066,949 million people according to the World Population Review (2020b).

Between 2003 and 2013, Liberia's per capita gross domestic product (GDP) grew steadily. The consolidation of peace and political stability combined with robust external assistance, rising foreign direct investment (FDI), and private sector-led growth in the context of a sound macroeconomic framework was fundamental to Liberia's economic recovery due to the 14 years civil conflict.

GDP expanded at an annual average rate of 6.2 percent between 2003 and 2013, but due to Liberia's high fertility rate, per capita GDP grew at a more modest of 3 percent per year and indicated by the World Bank Group (2018). Liberia's economy grew by an estimated 2.5 percent in 2017, as increased mining sector output compensated for the weak performance of other sectors.

Meanwhile, this resulted to a decline in domestic revenues generation and rising mandatory expenditures for the government. Due to poor governance and weak institutions, most investment focuses on the extractive industries, and firms in other sectors face major obstacles to doing business.

Liberia shares borders with its neighboring Côte d'Ivoire, Guinea, and Sierra Leone while Côte d'Ivoire, and Guinea have successfully improved their business environments within the region that has also enabled Liberian traders to participate in cross-border trade.

According to World Bank country report for 2018, Liberia faces complex development challenges, including a highly concentrated export structure, a narrow revenue base, a heavy reliance on foreign aid, a structural fiscal deficit, and an increasing dependence on commodities (food) imports. Transitioning to an economic model in which GDP growth reliably generates broad-based improvements in filling the poverty gap and social development indicators will require building human capital through education, boosting productivity, accelerating jobs creation by investment in industrial base agriculture and increase agribusiness and argo-processing opportunities among rural Liberians traders and then gradually open doors to real time cross-border trade.

Many of these challenges are also reflected in Liberia's national strategic vision, "Liberia Rising 2030" and addressing them will require well-designed, tightly coordinated, and properly sequenced policy interventions that will strengthen socioeconomic resilience, enhancing the quality of governance, and expanding institutional capacity.

International trade plays a fundamental role in diversifying any modern economy to emerge especially for Least Developed Countries. With export trade, it can be viewed as an engine of economic growth; an increase in the demand for domestic exportable products will certainly lead to increase in the overall nation output. Export growth countries can take the benefit from economies of scale. Further, increased exports can provide foreign exchange that can be used for 
import of new technology from developed economies Rani (2018).

Researchers and policymakers still believe that the open economies grow faster than that of the closed economy Rani (2018). According to the International Monetary Fund IMF, it was observed in 2011 that real global economic output sharply declined from 4.1percent in 2011 to 2.4 percent in April to 2013. This shrinkage in nationwide output has worsened living standards especially among the poorest people in the world as poverty levels have also deteriorated IMF (2013).

Historically, Firestone Tire and Rubber Company has been one of the engines behind Liberia's economy success, maintaining one of the largest rubber plantations in the world. This resulted to bilateral trade floor between Liberia and the Western World with Liberia having comparative advantage over agricultural produce in the exchange for finished goods that has broadened Liberian foreign earnings through export trade in raw agriculture commodities such as natural rubber, iron ore, cocoa, diamond, gold, and etc.

According to Firestone Tire and Rubber Company-Liberia, a total of USD $\$ 1.3$ billion was directly invested between 2004 and 2017, mainly through a combination of wages, salaries, healthcare, education, taxes to the Government, rubber purchased from Liberian (small) rubber farmers, and payments for goods and services (Firestone, 2019). These investments and among others are in addition to purchases of equipment and manufactured goods used in daily operations. Firestone Liberia continues to work towards returning the farm to full operational condition in the decades following 14 years of civil wars in Liberia (Firestone, 2019).

Liberia as a West African Nation is rich with mineral resources but yet remain poor in its human capital, and as well as lack infrastructural development in all sectors making it one of the poorest countries in the world according to World Population Review (2020a) and with a GNI per capita of $\$ 710$.

Most of the Least Developed countries in Sub-Sahara Africa in recent years have focused on foreign aid as a backbone for economic growth and development with less attention given to exports oriented industries that could increase national output and create employment for citizens. This study tends to fill the gap in the economic growth-determinants literature by examining the link between economic growth, imports, and export.

Also, promoting inclusive growth has been one of the main recent challenges in developing economies. Maximizing the benefit from foreign trade and closing the gap on import concentrated marked can help to promote pro-poor growth for least developed economies. In this vein, this study can be distinguished from previous studies by investigating the impact that imports and exports have on economic growth and development in Liberia.

\section{Review of Current Literature}

Empirical researches on the role of exports in achieving sustainable economic 
growth and developments have been carryon with findings showing a positive relationship between exports and economic growth and development. Exports and economic growth are found to have one-way causality relationship in Indonesia and Singapore and two-way causality relationship in Indonesia and the Philippines according to (Ismail, 2003).

Real income and real export growth are found to be co-integrated in Bangladesh (Love, 2005). Also, there is a unidirectional causality relationship between export growth and GDP growth in Denmark, Ireland, Italy, New Zealand, Belgium, Spain, Iceland, and Sweden; while on the other hand there is a bidirectional causality relationship export growth and GDP growth in Austria, Japan, France, Greece, Norway, Mexico, and Poland (Konya, 2006). There is a bidirectional causality relationship between export growth and real GDP growth in both short run and long run in Turkey for the period 1980-2007 (Taban, 2008).

Many countries of the world choose to trade with one another simply because trade has become advantageous to the growth of modern economy. Not only that but also, international trade has become even more beneficial to every nation whether rich or poor; it now serves as an engine for the global economy.

Over the years, several theories have been developed to explain the justification for international trade and its link with economic growth and development. These include absolute advantage theory (Smith, 1776); comparative advantage theory (Ricardo, 1817); product life cycle and national competitive advantage theory (Porter, 1990).

All these theories advocate free and unfettered trade among nations. Countries should abandon autarky (self-sufficiency) and embrace free trade. Srinivasan (1999) submits that trade liberalization (moving the economy to free trade from autarky) has positive growth effects on nation's economy (Cole, 2012), there is an avalanche of evidence (both theoretical and empirical) in the extant literature to show that exports are correlated with economic growth and development of countries developing and developed alike (Jung, 1985), (Levin, 1997), (Al-Yousif, 1999), (Giles, 2000), (Ullah, 2009), (Tabari, 2010) and (Rahmaddi, 2011). This export-growth nexus has been described by scholars as export-led growth (ELG) strategy/hypothesis (Love, 2005), (Ahmed, 2008) and (Sentsho, 2012).

ELG as Export Led-Growth is an economic development strategy in which export and foreign trade in general play a central role in a country's economic growth and development (Sentsho, 2012). In spite of the positive association between exports and economic growth in the developing countries, there are also evidences in the literature which negate this association. For instance, (Jaffee, 1985) questions whether a dependence on exports to lead the economy will result in constant long-term economic growth in lesser developed countries (LDCs), due to the volatility and unpredictability in the world market.

(Hsiao, 1987) employing Granger tests causality, shows that there is no causal relation between exports and GDP for four Asian newly industrializing econo- 
mies, except Hong Kong, where unidirectional causality run from GDP to exports. Also, (Bahmani-Oskooee, 1991) who similarly used Ganger concept of causality and did not find a strong evidence to support the ELG hypothesis in less developed countries (LDCs).

Liberia as a country emerging from a prolong war, and also labeled as one of the poorest countries in the world, international trade has impacted the nation's growth in one way or the other. The country's merchandise exports increased from negligible levels before the Second World War to US $\$ 400 \mathrm{~m}$. Looking back in 1974, stimulated by strong demand in the world economy for iron ore and supported by continuing exports of natural rubber and other primary agricultural commodities.

In 1974 exports were equivalent in value to 87 percent of GDP. Exports then stagnated in volume terms, in the late 1970s as a result of the global recession. In the 1980s the volume of exports declined and created some setbacks that affected the Liberian's economy. Nevertheless, the dominance of the export sector continued: exports were equivalent to 58 percent of GDP in 1980 and 50 percent in 1989.

In July of 2009, A case study was conducted whereas the case analysis uses Malawi in a paper published by the United States Department of Agriculture titling "Trade and Development -When Exports Lack Diversification" reported that a country that earns most of its foreign exchange from export concentration can be heavy exposure to volatility.

In most cases, the higher the volatility, the riskier the security. The econometric results from that suggest that the decline in Malawi's gross domestic product (GDP) at such a time when tobacco exportation is falling can be almost three times greater than the increase in GDP when exports are rising. For example, variability in cocoa beans exports could lead to slower economic growth for a country that is heavily relying on cocoa beans or cash-crop exportation because GDP falls by a relatively large amount in response to a given decrease in exports, while recovering little during an upswing in exports. However, an increase in cocoa beans for such a country could achieve greater GDP growth from variability in export earnings.

Since trade promotes economic development, countries must link each other in forming economic cooperation that can bring about sustainable economic growth and development. The adoption of international trade can serve as a useful stage to help every country accomplish its goal be it least developed or underdeveloped, wealthy or poor. International trade engagement can be very rewarding and advantageous to nations and their economic growth. I certainly also support (Love, 2005) base on the fact that export-led growth is an economic development strategy in which export and foreign trade in general play a central role in a country's economic growth and development.

For example, in West Africa, ECOWAS member country such as Nigeria is likely to have an abundance of some unique and different types of resources as 
compared to others with fewer and wider population gap. In economic reasoning, such a distribution ratio could be advantageous in trade facilitation and economic growth due to multiple factors. With the support of existent literature, the evidence is clear in both (theoretical and empirical research) that exports trade in relative commodities is correlated with economic growth and in the development of countries (Al-Yousif, 1999).

However, there are still some critical issues that are yet to be addressed when considering Liberia. In recent times, not too much research has been carryon or done to see the relationship or direct effects of Exports and GDP growth in Liberia as compared to other places. Notwithstanding, Andrews (2015) investigated the relationship between Exports, Imports, and Economic Growth in Liberia: Evidence from that study shows some favorable results using Causality and Cointegration Analysis. In his study, the results confirm the bi-directional causation between GDP and Imports and unidirectional causation between exports and GDP and exports and imports. Moreover, his analysis does not suggest that Liberia is driven by exports alone but rather a mixture of exports and imports commodities across sectors.

Uddin (2009) investigate the causally between export and GDP growth of Bangladesh taking import, remittance as a control variable; using annual data from 1976 to 2005. Their findings show limited support in favor of export-led growth hypothesis and for imports, remittance, and GDP. Also, Akhter (2017) investigates the relationship between import, export, and GDP growth. This study concluded that the impact of exports on economic growth is positive. An opposite scenario is also found in the case of import. All these researches investigated the relationship between export, import, and GDP growth by taking of different control variables like import and remittance. But no evidence found in the literature that considered gross fixed capital formation that happens to be a key component or element of GDP prediction.

It is in this vein that based on current literature review that this research is going to provide further evidence about the relationship between export and GDP growth and alongside with other variables like Gross Fixed Capital Formation, (GFCF) showing at what level does gross fixed capital formation contributes to the economic growth of Liberia and at the same time focusing on the impact of Liberia's exports on its economic growth.

\section{Data Sources and Model Specification}

The required data is collected from the World Bank Indicators (WBI) online database. Liberia has limited access to online data sources therefore it is difficult for researchers to find country data apart from those published in yearly reports and news articles. Since the World Bank and the International Monetary Fund, (IMF) has access to credible data sources, the researcher extracted the data from the World Bank online database Indicators. The research uses data from 2000 to 
2019 to employed a time series regression model of the Ordinary Least Squares (OLS) and technique by Stock and Wilson (1988) to analyze Liberia's trade performance using macroeconomic indicators/variables that has effect on economic growth such as, Exports, Foreign Direct Investment (FDI), Population, Imports, Gross Fixed Capital Formation, (GFCF) and gross domestic product (GDP) as key indicator of analysis. The study used annual time series data on the variables for the period 2000 to 2019 as seen in Table 1 on the next page. The data needs were identified based on the objectives of the study. Hence, the year 2000 and also 2003 can be regarded as a significant year since it was the period when the country was emerging from the heat of the 14 years conflict, (war).

\section{Model Presentation}

We formulate the equation as:

$$
Y_{t}=m X+b+\varepsilon_{t}
$$

\section{where:}

$Y_{i}$ : Dependent variable

$X_{i}$ Independent variable

$b$ : Constant term

$t$. Time trend

$\varepsilon_{i}$ is the random error term, which is the difference between the actual value of a dependent variable and its predicted value

Econometrically, the model for this research analysis will be stated as;

$$
Y=\beta_{0}+\beta_{1} X_{t}+\beta_{2} X_{t}+\beta_{3} X_{t}+\beta_{4} X_{t}+\beta_{5} X_{t}+\varepsilon_{t}
$$

where $Y_{t}$ is known as the Dependent variable, $\beta_{0}$ is known as the Intercept while $\beta_{1}, \beta_{2}, \ldots$ and $\beta_{5}$ are known as the Coefficients.

Thus;

$Y=\mathrm{RGDP}_{t}$

Table 1. Variables and interpretation.

\begin{tabular}{lll}
\hline Variable & Description & Data Source \\
\hline Dependent Variable & & Annual percentage growth rate of GDP per capita (\%) World Bank \\
RGDP per capital growth rate & Annual percentage growth rate of exports of goods & World Bank \\
Independent Variables & $\begin{array}{l}\text { and services } \\
\text { Exports of goods and services }\end{array}$ & World Bank \\
Imports of goods and services & Imports of goods and services (\% of GDP) & World Bank \\
Population growth rate & Annual population growth rate (\%) & World Bank \\
Gross fixed capital formation & Gross fixed capital formation (\% of GDP) & World Bank \\
\hline
\end{tabular}

Source: Author's Computation (2020). 


$$
\begin{aligned}
& \beta_{0}=\text { Intercept } \\
& \beta_{1}=\mathrm{EXP}_{t} \\
& \beta_{2}=\mathrm{IMP}_{t} \\
& \beta_{3}=\mathrm{GFCF}_{t} \\
& \beta_{4}=\mathrm{FDI} \\
& \beta_{5}=\mathrm{POP}_{t} \\
& \varepsilon_{t}=\text { Error term }
\end{aligned}
$$

The above equation can be expressed in a linear function given an empirical version of the research model as:

$$
\mathrm{RGDP}_{t}=\beta_{0}+\beta_{1}+\mathrm{EXP}_{t}+\beta_{2}+\mathrm{IMP}_{t}+\beta_{3}+\mathrm{GFCF}_{t}+\beta_{4}+\mathrm{FDI}_{t}+\beta_{5}+\mathrm{POP}_{t}+\varepsilon_{t}
$$

\section{Methodology}

Damodar N. Gujarati (2009) made it known that a model is simply a set of mathematical equations. If the model has only one equation, that means it is a single equation model but if the model has more than one equation, then it is classified as multiple-equation model. Therefore, the econometric method to be used in this research analysis is the Ordinary Least Square (OLS) regression method. This helps the researcher to estimate a favorable parameter of economic relationship mentioned in this study.

Based on the analysis of the regression result, the R-squared $\left(R^{2}\right)$ is giving as 0.973303452 and Adjusted R-squared (Adj- $R^{2}$ ) is 0.963768971 . Statistically, the data model shows a positive trend and significant correlation between gross domestic product (GDP) and the explanatory variables.

The result also shows negative relationship with Imports less than the theoretically expected value and also predicates a positive relationship between foreign direct investment (FDI) and GDP growth. Not only that, but also, the model predicates a positive relationship between population growth and GDP; while in the same vein there is a negative correlation between gross fixed capital formation (GFCF) and GDP growth.

\section{Data Analysis and Interpretation}

\subsection{Introduction}

In the previous chapter on page 2655 , a model was specified to find out the effect of Export, Import, Gross Fixed Capital Formation, Foreign Direct Investment and Population on Gross Domestic Product in Liberia. To examine this effect, data were analyzed using the Statistical Package for Social Sciences (SPSS), Version 20 .

\subsection{Data Presentation}

Table 2 below shows the data on Gross Domestic Product (GDP) $Y$, Export (EXP) $X_{1}$, Import (IMP) $X_{2}$, Gross Fixed Capital Formation (GFCF) $X_{3}$, Foreign Direct Investment $X_{4}$, Population (POP) $X_{5}$, from 2000 to 2019. 
Table 2. Regression coefficients.

\begin{tabular}{|c|c|c|c|c|c|c|c|}
\hline \multicolumn{8}{|l|}{ Coefficients } \\
\hline \multirow{2}{*}{ Model } & \multicolumn{2}{|c|}{ Unstandardized Coefficients } & \multicolumn{2}{|l|}{ Standardized Coefficients } & \multirow{2}{*}{ Sig. } & \multicolumn{2}{|c|}{ Collinearity Statistics } \\
\hline & B & Std. Error & Beta & & & Tolerance & VIF \\
\hline (Constant) & $-2,786,085,636.505$ & $369,614,983.555$ & & -7.538 & 0.000 & & \\
\hline $\begin{array}{l}\text { Gross Fixed Capital } \\
\text { Formation }\end{array}$ & $-10,456,460.947$ & $12,199,827.432$ & -0.038 & -.857 & 0.406 & 0.949 & 1.053 \\
\hline Population & 1316.933 & 75.402 & 0.888 & 17.465 & 0.000 & 0.738 & 1.355 \\
\hline Import & $-2,567,433.478$ & $919,646.526$ & -0.157 & -2.792 & 0.014 & 0.602 & 1.660 \\
\hline Export & 0.672 & 0.260 & 0.161 & 2.581 & 0.022 & 0.490 & 2.043 \\
\hline $\begin{array}{l}\text { Foreign Direct } \\
\text { Investment }\end{array}$ & 0.060 & 0.059 & 0.049 & 1.026 & 0.322 & 0.845 & 1.184 \\
\hline
\end{tabular}

a. Dependent Variable: Gross Domestic Product. Source: Author's Computation using SPSS Version 20.

\subsection{Testing for Multicollinearity}

We test for multicollinearity i.e. if the independent variables can be written as a linear combination of each other. Two values are used to check for the presence of multicollinearity. These are Tolerance and the Variance Inflation Factor (VIF). Tolerance is an indicator of how much of the variability specified independent variable is not explained by the other independent variables in the model and it is calculated as $1-\mathrm{R}$ squared for each variable. The VIF is the inverse of the Tolerance. Also, in testing for multicollinearity, the values less than 0.1 and VIF values greater than 10 indicate the presence of multicollinearity. Considering the Collinearity Statistics in Table 2 below, all the Tolerance values are greater than 0.1 and all the VIF values are less than 10 . This indicates the absence of multicollinearity see in Table 2 .

\subsection{Evaluating the Model}

\section{1) Checking for Variation Explained by the Independent Variables}

From Table 3 below, the value of $R$ square is 0.973 which means that $97.3 \%$ of the total variation in Gross Domestic Product is accounted for by the inclusion of the five independent variables (Export, Import, Gross Fixed Capital Formation, Foreign Direct Investment and Population) in the fitted model.

$$
\begin{aligned}
\operatorname{RGDP}_{t}= & -2786085636.505+0.672 \mathrm{EXP}_{t}-2567433.478 \mathrm{IMP}_{t} \\
& -10456460.947 \mathrm{GFCF}_{t}+0.060 \mathrm{FDI}_{t}+1316.933 \mathrm{POP}_{t}+\varepsilon_{t}
\end{aligned}
$$

\section{2) Checking for Model Significance}

To assess the statistical significance of the result, we consider the Analysis of Variance (ANOVA) table. The null hypothesis tested here is that the multiple $\mathrm{R}$ in the population equals 0 . That is, $H_{0}: R=0$.

From the ANOVA table below (Table 4), the F calculated is equal to 102.082 and has a p-value of .000 (as seen in the Sig. Column below). Since the p-value is less than $0.05(p<0.05)$, I reject the null hypothesis and conclude that the model is statistically significant. 
Table 3. Model summary.

\begin{tabular}{ccccc}
\hline Model & R & R Square & Adjusted R Square & Std. Error of the Estimate \\
\hline 1 & $0.987^{\mathrm{a}}$ & 0.973 & 0.964 & $191,935,223.832$ \\
\hline \multicolumn{2}{l}{ a. Predictors: (Constant), Foreign Direct Investment, Gross Fixed Capital Formation, Import, Population, Export; b. Dependent Variable: Gross Domestic }
\end{tabular}

Product. Source: Author's Computation using SPSS Version 20.

Table 4. Analysis of variance.

\begin{tabular}{|c|c|c|c|c|c|c|}
\hline \multicolumn{7}{|c|}{ ANOVA $^{\mathrm{a}}$} \\
\hline Model & & Sum of Squares & df & Mean Square & $\mathrm{F}$ & Sig. \\
\hline \multirow{3}{*}{1} & Regression & $18,803,147,883,745,018,000.000$ & 5 & $3,760,629,576,749,003,300.000$ & 102.082 & $0.000^{\mathrm{b}}$ \\
\hline & Residual & $515,747,822,065,559,550.000$ & 14 & $36,839,130,147,539,968.000$ & & \\
\hline & Total & $19,318,895,705,810,575,000.000$ & 19 & & & \\
\hline
\end{tabular}

a. Dependent Variable: Gross Domestic Product; b. Predictors: (Constant), Foreign Direct Investment, Gross Fixed Capital Formation, Import, Population, Export. Source: Author's Computation using SPSS Version 20.

\subsection{Evaluating Each Independent Variable}

\section{1) Contribution of the Variables}

Considering the column for Beta under Standardized coefficients in Table 2 where the values for each of the variables have been converted to the same scale to enable comparison, we can check and compare the individual contribution of the independent variables.

From the Beta column we see that population has the largest beta coefficient (0.888), followed by Export (0.161), then Import $(-0.157)$, then Foreign Direct Investment (0.049) and lastly, Gross Fixed Capital Formation (-0.038).

The implication is that population made the strongest unique contribution to explaining the dependent variable, when the variance explained by all other variables in the model is controlled for while Gross Fixed Capital Formation made the least unique contribution to explaining the dependent, when the variance explained by all other variables in the model is for.

\section{2) Significance of the Betas}

Considering the Sig. column in Table 2, we check to see if the unique contribution of the independent variables is statistically significant.

The p-values for Population, Import and Export are less than 0.05, indicating that they make statistically significant unique contributions to the prediction of the GDP.

\section{3) Regression Equation and Interpretation}

Considering the Unstandardized Coefficients in Table 2, we can find the regression equation.

From the table, the regression equation is:

$$
\begin{aligned}
\mathrm{RGDP}_{t}= & -2786085636.505+0.672 \mathrm{EXP}_{t}-2567433.478 \mathrm{IMP}_{t} \\
& -10456460.947 \mathrm{GFCF}_{t}+0.060 \mathrm{FDI}_{t}+1316.933 \mathrm{POP}_{t}+\varepsilon_{t}
\end{aligned}
$$

That is, 


$$
\begin{aligned}
\hat{Y}= & -2786085636.505+0.672 X_{1}-2567433.478 X_{2} \\
& -10456460.947 X_{3}+0.060 X_{4}+1316.933 X_{5}
\end{aligned}
$$

From the equation above we have the following interpretations:

- In the absence of the independent variables, the real GDP is -2,786,085,636.505.

- The coefficient of $X_{1}$ means that for every unit change in the value of export there is 0.672 increase in GDP while other variables are held constant.

- The coefficient of $X_{2}$ means that for every unit change in import, there will be a decrease of 2,567,433.478 in Gross Domestic Product while other variables held constant.

- The coefficient of $X_{3}$ means for every unit change in Gross Fixed Capital Formation, there will be a decrease of $10,456,460.947$ in Gross Domestic Product while other variables held constant.

- The coefficient of $X_{4}$ means for every unit change in Foreign Direct Investment, there will be an increase of 0.060 in Gross Domestic Product while other variables are held constant.

- The coefficient of $X_{5}$ means for every unit change in Population, there will be an increase of 1316.933 in Gross Domestic Product while other variables held constant.

\section{4) Prediction of GDP}

To predict GDP values for 2020 to 2023, the regression equation is employed. Predicted values are presented in Table 5 below. The predicted values indicate that there will be a decline in GDP for the years 2020 to 2023.

Since the term, "Economic Growth" is in one way or the other associated and reliance on the progress of people to produce a certain amount of goods and services within a specific period, and to meet the needs and wants of individuals in the society, the employment of people and better wages could be a way out in the short run and in the long-run, to invest in human capital since it is significantly related to long term economic prosperity. A sustained economic growth of a nation has a positive impact on the national income and the level of employment, that could result in higher living standards of people. Employment as a whole plays a vital role in stimulating domestic income for government tax and revenue generation. When there is no job and people are not employed, it becomes impossible for the government to generate domestic revenue. And in the absence of that, the government will not function to the fullest. When people are employed, it allows the government to earn extra income to carry on its daily operations and at the same time raising government Gross National Income while in the same vein allowing her to carry on its economic activity.

Therefore, doing this projection and economic analysis will serve as an alert to stakeholders in addressing different economic problems, such as high inflation, depreciation of the domestic currency, and economic instability. Because economic growth is directly correlated to the percentage increase in gross national product for a given period, therefore, economic growth is the increase in per capita national output. In that case, if there be any decline in the total output it 
Table 5. Predicted GDP Values.

\begin{tabular}{|c|c|c|c|}
\hline Year & Actual GDP & Predicted GDP & Residual \\
\hline 2000 & $874,000,000$ & $884,291,690$ & $-10,291,690$ \\
\hline 2001 & $906,000,000$ & $882,808,026$ & $23,191,974$ \\
\hline 2002 & $927,000,000$ & $927,752,797$ & $-752,797$ \\
\hline 2003 & $748,000,000$ & $949,350,654$ & $-201,350,654$ \\
\hline 2004 & $897,000,000$ & $653,952,272$ & $243,047,728$ \\
\hline 2005 & $949,000,000$ & $934,447,086$ & $14,552,914$ \\
\hline 2006 & $1,119,000,000$ & $1,005,682,285$ & $113,317,715$ \\
\hline 2007 & $1,373,000,000$ & $1,241,819,170$ & $131,180,830$ \\
\hline 2008 & $1,726,000,000$ & $1,576,678,278$ & $149,321,722$ \\
\hline 2009 & $1,768,000,000$ & $2,021,816,975$ & $-253,816,975$ \\
\hline 2010 & $1,998,000,000$ & $1,923,781,140$ & $74,218,860$ \\
\hline 2011 & $2,398,000,000$ & $2,185,369,413$ & $212,630,587$ \\
\hline 2012 & $2,721,000,000$ & $2,711,558,710$ & $9,441,290$ \\
\hline 2013 & $3,067,000,000$ & $3,049,485,086$ & $17,514,914$ \\
\hline 2014 & $3,144,000,000$ & $3,406,027,822$ & $-262,027,822$ \\
\hline 2015 & $3,177,000,000$ & $3,332,376,406$ & $-155,376,406$ \\
\hline 2016 & $3,277,826,000$ & $3,263,910,968$ & $13,915,032$ \\
\hline 2017 & $3,285,455,000$ & $3,365,858,673$ & $-80,403,673$ \\
\hline 2018 & $3,264,000,000$ & $3,327,640,411$ & $-63,640,411$ \\
\hline 2019 & $3,070,518,100$ & $3,265,825,270$ & $-195,307,170$ \\
\hline 2020 & & $2,956,636,785$ & \\
\hline 2021 & & $2,834,056,960$ & \\
\hline 2022 & & $2,711,477,135$ & \\
\hline 2023 & & $2,588,897,310$ & \\
\hline
\end{tabular}

Source: Author's Computation using SPSS Version 20.

would lead to a low standard of living of the people even if there becomes an increase in the total population.

All in all, economic growth for Liberia may hamper due to multiple factors, such as trade deficit, high inflation, depression of local currency, economic instability, and alteration in expenditures by government. Also, because Liberia is heavily driven and reliance on import commodities, its economy is vulnerable to external shocks, so, therefore, it is adversely affected when there is a sharp increase in the prices of services and commodities for both locally and internationally.

These are some contributing factors that may lead to a decline in the predicted GDP values for the years 2020 to 2023 . To approach some of these factors, there are keys recommendations that the study highlighted at the end of the paper for policy implementation.

Poor human capital factors:

The level of national human capital resource can directly affect the growth of 
its economy. Liberia is lacking quality human capital resources, and therefore, the creative abilities of it people are low because of unqualified and in balance skills of people due to the lack of education. For a country to achieve cutting edge growth, her human resource needs to be well skilled and trained so that output would also be of high quality. On the other hand, a shortage of skilled labor in any economy can hamper the growth of such an economy, and therefore, the human capital resources of a country should be adequate so that economic growth can be achieved.

Since Liberia is reliant on extractive industries of mainly agriculture commodities and intensively driven by iron ore mining and natural rubber cultivation for export, with skilled and educated workforce could help maximize revenue and place the economy on a steady growth path.

For instance, in some extreme cases, there are countries that have few natural resources, but with a high per capita income, such as Saudi Arabia with high economic growth. Similarly, Japan has a small natural resource but achieves a high growth rate due to the efficiency of its human resource, and technological advancement. Liberia, on the other hand, is small geographically, and has abounded natural resources, but yet remains poor in its physical state and periodically records low growth rate due to its inefficient human capital.

\section{Discussion}

Study conducted on import and export-lead promotion and innovation is still underway and emerging as researchers face difficulties in comparing each other's findings. There are some difficulties in undertaking academic research papers that investigate the impact factors of import, and export effect on economic growth that researchers use different analysis tools and as well as variables in measuring and explaining import, export with economic growth, and development. Due to these factors, researchers only can reach popular variables that are backed by available data to make decisions. For example, most of the least developed countries lack access to data, so researchers find that difficult and try to make use of variables that can be supported by data. For example, in Liberia, there is a lack of research to combine findings and make a comparative analysis between different studies from different regions. These and many others make this research somehow limited to a specific area.

\section{Conclusion and Policy Implication}

This study aimed to determine the impact of Liberia's exports, imports on its economic growth from the period 2000-2019. The study employed a time series regression model of the Ordinary Least Squares (OLS) technique between the variables; Exports, Foreign Direct Investment (FDI), Population, Imports, Gross Fixed Capital Formation, (GFCF) and Gross Domestic Product (GDP).

The result shows that there is an association between population growth, export, FDI, and the economic growth of Liberia. Also, import and Gross Fixed 
Capital Formation turn out to be negative and statistically insignificant in the model. From the OLS test, statistically, it is proven that imports and Gross Fixed Capital Formation do not account for economic growth in Liberia. While the results for exports and population in the model are seeing as a source of economic growth for Liberia.

International trade especially with commodities in exports can explain not only the changes in output volume within the short-run but also in the long-run.

The research finding also conforms with (Ee, 2016) idea of the effect of export-led growth to be positive and statistically significant. To some extent, these theories have been explained to justified international trade and its link with economic growth and development. These include absolute advantage theory by Adam Smith, comparative advantage theory by David Ricardo in 1817, national factor endowment theory, and also the national competitive advantage theory (Porter, 1990).

Last but not least, the empirical findings offer important policy implications for stakeholders. That Liberia should formulate a stable macroeconomic environment that is favorable to attract foreign direct investment, improve on infrastructure, focus on education and strengthen human capital for long-term output, shifting from subsistence farming dominated by women to a more unique and market-oriented agricultural productivity based. By doing this will yield the most favorable effects on economic growth. Moving to the determinants of export diversification, this analysis confirms a positive relationship between the degree of diversification and the development of a country, as represented by the significant positive coefficient of real GDP.

\section{Study Limitations}

Lack of obtainable and/or reliable data - the shortage of a country's data or of reliable data from the Ministry of Commerce and Industry leads the researcher to form use of these data available from the World Bank online database and indicator. Even though the database is extensively used and trusted for decision making, it is also important to work with first-hand country data for reliability and powerful decision-making purposes. Also, thanks to the supply of knowledge, the study limits the scope of the analysis, the dimensions of the sample. The previous political instability also places a big role that limits the scope of the study due to the shortage of missing data at the country level and also from the international level as well. There's still a requirement for future research if one can widen the scope to seek out more answer concerning the subject.

Lack of prior research studies on the subject-Geographically, citing prior research and studies associated with the subject may be a challenge to deal with the subject specifically in Liberia. There's a good range of literature and studies conducted on the subject across other regions, but not with the case of Liberia. Therefore, when addressing the subject, one must be very careful. The concept could also be an equivalent but application isn't alike due to location, different 
resources, size, culture, systems of state, etc.

\section{Key Recommendations for Policy Implications}

Based on the research result presented, the researcher would like to suggest to policymakers the below points for policy implementation.

Revitalizing the Liberian economy in the future will depend on strong economic diversification, increasing agricultural investment and trade facilitation, development of infrastructure and strengthening of institutions, combating corruption, and maintaining political stability and security.

Liberia imports up to 60 percent of its staple food (rice) and other commodities. Agriculture is central to Liberia's vision of economic transformation. However, smallholder farmers are held back by lack of fertilizer and irrigation, poor seeds and breeding stock; and an inadequate credit facility, machinery, and infrastructure for transport, storage, and marketing. Liberia also needs to develop a food processing industry.

For job creation and sustainable long-term economic growth, Liberia needs to build an industrialized economy with the development of at least one factory or enterprise in each of its 15 counties or political sub-division to facilitate rural employment and create new jobs. By doing this will help increase agricultural and manufacturing output and reduce her reliance on large imports of foreign goods, especially in food commodities. Not only that, but also investment in agriculture will increase agribusiness and argo-processing opportunities among rural Liberians and then gradually open doors to cross-border trade.

- Since GDP is dependent on export and foreign direct investment for economic growth, I would therefore recommend that the government of Liberia pays keen attention to sectors like agriculture and manufacturing, as well as investing more money (capital) into a large-scale farming system to increase the level of employment and a production strategy for achieving rapid economic growth.

- Since the mining of iron ore diamond and gold has an impact on the industrial exports of minerals that contribute to economic growth, the government should diversify those investments to create more jobs for the locals so as to yield more output.

- The expansion in exports of mainly agricultural commodities should be given more emphasis and priority in Liberia since the nation has favorable climate and natural resources that are suitable for agricultural purposes.

- Liberia should reduce or cut-off the importation of rice and empower local Liberian farmers to grow their food and to fix the prolonged challenges faced in the continued shortage of rice on the Liberian market.

- Liberia should increase the rate of growth and diversify its agricultural product exports in other to increase her export volume, improve the product's standard, and expand on creating new agricultural products and markets for export.

- To create a vibrant market research institute for agricultural product testing. 
- Besides, the government should also promote and create an industrial agriculture factory for food testing.

- "Holding all other factors constant" (Ceteris paribus), with no doubt, regardless of change in future leadership and policies reforms, and as well as corruption, if Liberian should develop, its government needs to focus on key issues like human capital development especially in the area of education provision. Liberia should embark on large scale agriculture base production so that by the year 2040, the nation can achieve some level of development and to close on the poverty gap and food security.

\section{Conflicts of Interest}

The authors declare no conflicts of interest regarding the publication of this paper.

\section{References}

Ahmed, A. D. (2008). The Role of Exports, FDI and Imports in Development: New Evidence from Sub-Saharan African Countries. Centre for Strategic Economic Studies, Working Paper No. 39.

Al-Yousif, Y. K. (1999). On the Role of Exports in the Economic Growth of Malaysia: A Multivariate Analysis. International Economic Journal, 13, 67-75. https://doi.org/10.1080/10168739900000006

Andrews, A. P. (2015). Exports, Imports, and Economic Growth in Liberia: Evidence from Causality and Cointegration Analysis. https://pdfs.semanticscholar.org/e423/9bd636c076456ad01410b900f082a79bc646.pdf

Bahmani-Oskooee, M. M. (1991). Exports, Growth and Causality in LDCs: A Reexamination. Journal of Development Economics, 36, 405-415. https://doi.org/10.1016/0304-3878(91)90044-V

Cole, A. A. (2012). Role of Export in Simulating Economic Growth and Development in Nigeria. In Proceedings of 2012 National Conference on National Security and Economic Development for Democratic Consolidation (pp. 1-3). Ikorodu, Lagos State, Nigeria: Researchgate.

https://www.researchgate.net/profile/Suraju_Aminu/publication/327445547_role_of_e xport_in_stimulating_economic_growth_and_development_in_nigeria/links/5b8fed3f 299bf114b7f6cd48/role-of-export-in-stimulating-economic-growth-and-development-i n-nigeria.pdf

Ee, C. Y. (2016). Export-Led Growth Hypothesis: Empirical Evidence From. Procedia Economics and Finance, 35, 232-240. https://doi.org/10.1016/S2212-5671(16)00029-0

Firestone (2019). Investing in Liberia. Monrovia: Firestone Natural Rubber Company Liberia. https://www.firestonenaturalrubber.com

Giles, A. J. (2000). Export-Led Growth: A Survey of the Empirical Literature and Some Non-Causality Results Part 1. Econometric Working Paper, EWP0001, Victoria: University of Victoria. https://doi.org/10.2139/ssrn.146208

Hsiao, M. C. (1987). Tests of Causality and Exogeneity between Exports and Economic Growth: The Case of the Asian NICs. Journal of Economics Development, 12, 143-159.

IMF (2013). World Economic Outlook April 2013. Washington DC: International Monetary Fund. http://www.imf.org/external/pubs/ft/weo/2013/01/pdf/text.pdf 
Ismail, A. G. (2003). Export and Economic Growth: The Causality Test for ASEAN Countries. Journal Ekonomi Pembangunan, 8, 89-95.

Jaffee, D. (1985). Export Dependence and Economic Growth: A Reformulation and Respecification. Social Forces, 64, 102-118. https://doi.org/10.1093/sf/64.1.102

Jung, W. S. (1985). Exports, Growth and Causality in Development Countries. Journal of Development Economist, 18, 1-12. https://doi.org/10.1016/0304-3878(85)90002-1

Konya, L. (2006). Exports and Growth: Granger Causality Analysis on OECD Countries with a Panel Data Approach. Economic Modelling, 23, 978-992. https://doi.org/10.1016/j.econmod.2006.04.008

Levin, A. A. (1997). Complementarities between Exports and Human Capital: Evidence from the Semi-Industrialized Countries. Economic Development and Cultural Change, 46, 155-174. https://doi.org/10.1086/452325

Love, J. A. (2005). Testing Export-Led Growth in Bangladesh in a Multivariate VAR Framework. Journal of Asian Economics, 15, 1155-1168. https://doi.org/10.1016/j.asieco.2004.11.009

Porter, M. E. (1990). The Competitive Advantage of Nation. New York: Free Press. https://doi.org/10.1007/978-1-349-11336-1

Rahmaddi, R. A. (2011). Exports and Economic Growth in Indonesia: A Causality Approach Based on Multi-Variate Error Correction Model. Journal of International Development and Cooperation, 17, 53-73.

Rani, K. (2018). Is There an Export- or Import-Led Growth in BRICS Countries? An Empirical Investigation. Jindal Journal of Business Research, 7, 13-23. https://doi.org/10.1177/2278682118761748

Ricardo, D. (1817). On the Principles of Political Economy and Taxation (3rd ed.). London. https://socialsciences.mcmaster.ca/econ/ugcm/3ll3/ricardo/Principles.pdf

Sentsho, J. (2012). Export Revenues as Determinants of Economic Growth: Evidence from Botswana. Economic Society of South Africa. http://www.essa.org.za

Smith, A. (1776). The Wealth of Nations. New York: Random House of Canada Limited, Toronto: Random House, Inc.

Srinivasan, T. N. (1999). Trade Orientation, Trade Liberalization, and Economic Growth. In G. R. Saxonhouse, \& T. N. Srinivasan (Eds.), Development, Duality, and the International Economic Regime. Ann Arbor, MN: The University of Michigan Press.

Taban, S. A. (2008). An Empirical Examination of the Export-Led Growth Hypothesis in Turkey. Journal of Yasar University, 3, 1535-1551.

Tabari, N. A. (2010). A Study of the Effects of Non-Oil Exports on Iranian Economic Growth. International Conference on EURASIAN Economies, 302-308.

Uddin, H. A. (2009). Export, Imports, Remittance and Growth in Bangladesh: An Empirical Analysis. Trade and Development Review, 79-92.

Ullah, Z. F. (2009). Cointegration and Causality between Exports and Economic Growth in Pakistan. European Journal of Social Sciences, 10, 23-35.

World Bank Group (2018). From Growth to Development: Priorities for Sustainably Reducing Poverty and Achieving Middle-Income Status by 2030. Monrovia: World Bank Group.

http://documents.worldbank.org/curated/en/585371528125859387/pdf/LBR-SCD-draft -10-06012018.pdf

World Population Review (2020a). Liberia Population 2020 (Live). 
https://worldpopulationreview.com/countries/liberia-population

World Population Review (2020b). Poorest Countries in the World Ranking. https://worldpopulationreview.com/country-rankings/poorest-countries-in-the-world 


\section{Appendix A}

Table S1. Data Used in this Study.

\begin{tabular}{|c|c|c|c|c|c|c|}
\hline Year & GDP & EXP & IMP & GFCF & FDI & POP \\
\hline 2000 & $874,000,000$ & 0 & 38.93697941 & 7.500091533 & $20,800,000$ & $2,848,456$ \\
\hline 2001 & $906,000,000$ & 0 & 31.41842163 & 26.10364238 & $8,300,000$ & $2,953,927$ \\
\hline 2002 & $927,000,000$ & 0 & 30.77900755 & 26.10312837 & $2,800,000$ & $3,024,729$ \\
\hline 2003 & $748,000,000$ & 0 & 35.86298128 & 23.79807487 & $372,220,000$ & $3,077,058$ \\
\hline 2004 & $897,000,000$ & $317,182,835.8$ & 222.877592 & 21.27659978 & $75,351,731.65$ & $3,135,651$ \\
\hline 2005 & $949,000,000$ & $345,501,547.3$ & 211.2727081 & 19.45454162 & $82,802,111.44$ & $3,218,116$ \\
\hline 2006 & $1,119,000,000$ & $491,132,628.9$ & 194.6923146 & 19.45433423 & $107,856,671.5$ & $3,329,211$ \\
\hline 2007 & $1,373,000,000$ & $542,371,782.8$ & 236.3909687 & 19.45388201 & $131,637,661.6$ & $3,461,911$ \\
\hline 2008 & $1,726,000,000$ & $758,569,895.6$ & 144.7285052 & 19.50143685 & $283,536,077.4$ & $3,607,860$ \\
\hline 2009 & $1,768,000,000$ & $454,072,818.5$ & 94.94700226 & 19.45461538 & $127,803,424.5$ & $3,754,133$ \\
\hline 2010 & $1,998,000,000$ & $325,037,491$ & 92.63478478 & 19.45463463 & $2,064,680,994$ & $3,891,356$ \\
\hline 2011 & $2,398,000,000$ & $395,093,823.5$ & 94.46034195 & 19.45451209 & $2,086,006,933$ & $4,017,443$ \\
\hline 2012 & $2,721,000,000$ & $354,972,616.8$ & 89.25380375 & 19.45433664 & $2,309,981,241$ & $4,135,659$ \\
\hline 2013 & $3,067,000,000$ & $647,927,006.9$ & 96.41356374 & 19.45440496 & $1,998,675,366$ & $4,248,334$ \\
\hline 2014 & $3,144,000,000$ & $690,084,044.6$ & 108.536514 & 19.49329517 & $501,870,828.6$ & $4,359,505$ \\
\hline 2015 & $3,177,000,000$ & $482,196,119.2$ & 106.5486623 & 20.15732452 & $232,679,832.5$ & $4,472,230$ \\
\hline 2016 & $3,277,826,000$ & $366,424,243.8$ & 100.2598063 & 20.08404351 & $311,699,760.3$ & $4,586,788$ \\
\hline 2017 & $3,285,455,000$ & $429,591,652.9$ & 98.70568917 & 20.48614575 & $247,842,983$ & $4,702,228$ \\
\hline 2018 & $3,264,000,000$ & $527,345,230.8$ & 94.33210784 & 18.29044118 & $129,129,754.8$ & $4,818,977$ \\
\hline 2019 & $3,070,518,100$ & 0 & 98.72694774 & 22.81557305 & 0 & $4,937,374$ \\
\hline
\end{tabular}

Source: Author's Computation (2020).

\section{Appendix B}

\begin{tabular}{|c|c|c|c|c|c|c|c|c|}
\hline SUMMARY OUTPUT & & & & & & & & \\
\hline \multicolumn{9}{|c|}{ Regression Statistics } \\
\hline Multiple R & 0.99 & & & & & & & \\
\hline R Square & 0.97 & & & & & & & \\
\hline Adjusted R Square & 0.96 & & & & & & & \\
\hline Standard Error & 191935223.83 & & & & & & & \\
\hline Observations & 20.00 & & & & & & & \\
\hline \multicolumn{9}{|l|}{ ANOVA } \\
\hline & $d f$ & SS & $M S$ & $\boldsymbol{F}$ & Significance $F$ & & & \\
\hline Regression & 5.00 & 18803147883738900000.00 & 3760629576747780000.00 & 102.08 & 0.00 & & & \\
\hline Residual & 14.00 & 515747822071660000.00 & 36839130147975700.00 & & & & & \\
\hline \multirow[t]{2}{*}{ Total } & 19.00 & 19318895705810600000.00 & & & & & & \\
\hline & Coefficients & Standard Error & $t_{\text {Stat }}$ & P-value & Lower 95\% & Upper 95\% & Lower $95.0 \%$ & Upper $95.0 \%$ \\
\hline Intercept & -2786085636.44 & 369614983.58 & -7.54 & 0.00 & -3578830932.88 & -1993340340.01 & -3578830932.88 & -1993340340.01 \\
\hline GFCF & -10456460.95 & 12199827.43 & -0.86 & 0.41 & -36622488.42 & 15709566.52 & -36622488.42 & 15709566.52 \\
\hline POP & 1316.93 & 75.40 & 17.47 & 0.00 & 1155.21 & 1478.66 & 1155.21 & 1478.66 \\
\hline IMP & -2567433.48 & 919646.53 & -2.79 & 0.01 & -4539879.11 & -594987.85 & -4539879.11 & -594987.85 \\
\hline EXP & 0.67 & 0.26 & 2.58 & 0.02 & 0.11 & 1.23 & 0.11 & 1.23 \\
\hline FDI & 0.06 & 0.06 & 1.03 & 0.32 & -0.07 & 0.19 & -0.07 & 0.19 \\
\hline
\end{tabular}

Figure S1. Ordinary Least Square Result. Source: Author's Computation (2020). 


\section{Appendix C}

Table S2. Regression Coefficients.

\begin{tabular}{|c|c|c|c|c|c|c|c|}
\hline \multicolumn{8}{|l|}{ Coefficients } \\
\hline \multirow{2}{*}{ Model } & \multicolumn{2}{|c|}{ Unstandardized Coefficients } & \multicolumn{2}{|l|}{ Standardized Coefficients } & \multirow{2}{*}{ Sig. } & \multicolumn{2}{|c|}{ Collinearity Statistics } \\
\hline & B & Std. Error & Beta & & & Tolerance & VIF \\
\hline (Constant) & $-2,786,085,636.505$ & $369,614,983.555$ & & -7.538 & 0.000 & & \\
\hline Gross Fixed Capital Formation & $-10,456,460.947$ & $12,199,827.432$ & -0.038 & -.857 & 0.406 & 0.949 & 1.053 \\
\hline Population & 1316.933 & 75.402 & 0.888 & 17.465 & 0.000 & 0.738 & 1.355 \\
\hline Import & $-2,567,433.478$ & $919,646.526$ & -0.157 & -2.792 & 0.014 & 0.602 & 1.660 \\
\hline Export & 0.672 & 0.260 & 0.161 & 2.581 & 0.022 & 0.490 & 2.043 \\
\hline Foreign Direct Investment & 0.060 & 0.059 & 0.049 & 1.026 & 0.322 & 0.845 & 1.184 \\
\hline
\end{tabular}

a. Dependent Variable: Gross Domestic Product.

\section{Appendix D}

Table S3. Model summary.

\begin{tabular}{ccccc}
\hline Model & $\mathbf{R}$ & R Square & Adjusted R Square & Std. Error of the Estimate \\
\hline 1 & $0.987^{\mathrm{a}}$ & 0.973 & 0.964 & $191,935,223.832$ \\
\hline
\end{tabular}

a. Predictors: (Constant), Foreign Direct Investment, Gross Fixed Capital Formation, Import, Population, Export; b. Dependent Variable: Gross Domestic Product.

\section{Appendix E}

Table S4. Analysis of Variance.

\begin{tabular}{|c|c|c|c|c|c|c|}
\hline \multicolumn{7}{|c|}{ ANOVA $^{\mathrm{a}}$} \\
\hline & Model & Sum of Squares & df & Mean Square & $\mathbf{F}$ & Sig. \\
\hline \multirow{3}{*}{1} & Regression & $18,803,147,883,745,018,000.000$ & 5 & $3,760,629,576,749,003,300.000$ & 102.082 & $0.000^{\mathrm{b}}$ \\
\hline & Residual & $515,747,822,065,559,550.000$ & 14 & $36,839,130,147,539,968.000$ & & \\
\hline & Total & $19,318,895,705,810,575,000.000$ & 19 & & & \\
\hline
\end{tabular}

a. Dependent Variable: Gross Domestic Product; b. Predictors: (Constant), Foreign Direct Investment, Gross Fixed Capital Formation, Import, Population, Export. Source: Author's Computation (2020). 


\section{Appendix F}

Table S5. Predicted GDP Values.

\begin{tabular}{|c|c|c|c|}
\hline Year & Actual GDP & Predicted GDP & Residual \\
\hline 2000 & $874,000,000$ & $884,291,690$ & $-10,291,690$ \\
\hline 2001 & $906,000,000$ & $882,808,026$ & $23,191,974$ \\
\hline 2002 & $927,000,000$ & $927,752,797$ & $-752,797$ \\
\hline 2003 & $748,000,000$ & $949,350,654$ & $-201,350,654$ \\
\hline 2004 & $897,000,000$ & $653,952,272$ & $243,047,728$ \\
\hline 2005 & $949,000,000$ & $934,447,086$ & $14,552,914$ \\
\hline 2006 & $1,119,000,000$ & $1,005,682,285$ & $113,317,715$ \\
\hline 2007 & $1,373,000,000$ & $1,241,819,170$ & $131,180,830$ \\
\hline 2008 & $1,726,000,000$ & $1,576,678,278$ & $149,321,722$ \\
\hline 2009 & $1,768,000,000$ & $2,021,816,975$ & $-253,816,975$ \\
\hline 2010 & $1,998,000,000$ & $1,923,781,140$ & $74,218,860$ \\
\hline 2011 & $2,398,000,000$ & $2,185,369,413$ & $212,630,587$ \\
\hline 2012 & $2,721,000,000$ & $2,711,558,710$ & $9,441,290$ \\
\hline 2013 & $3,067,000,000$ & $3,049,485,086$ & $17,514,914$ \\
\hline 2014 & $3,144,000,000$ & $3,406,027,822$ & $-262,027,822$ \\
\hline 2015 & $3,177,000,000$ & $3,332,376,406$ & $-155,376,406$ \\
\hline 2016 & $3,277,826,000$ & $3,263,910,968$ & $13,915,032$ \\
\hline 2017 & $3,285,455,000$ & $3,365,858,673$ & $-80,403,673$ \\
\hline 2018 & $3,264,000,000$ & $3,327,640,411$ & $-63,640,411$ \\
\hline 2019 & $3,070,518,100$ & $3,265,825,270$ & $-195,307,170$ \\
\hline 2020 & & $2,956,636,785$ & \\
\hline 2021 & & $2,834,056,960$ & \\
\hline 2022 & & $2,711,477,135$ & \\
\hline 2023 & & $2,588,897,310$ & \\
\hline
\end{tabular}

b. Source: Author's Computation (2020). 


\section{Appendix G}

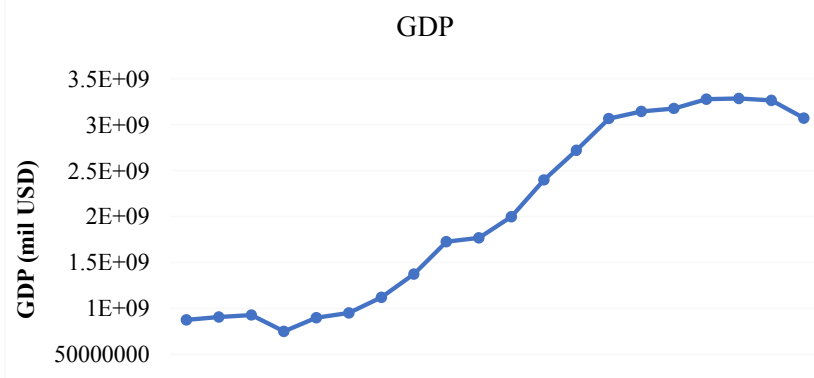

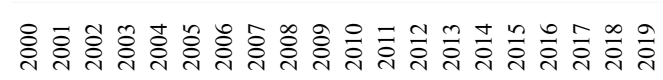

Figure S2. GDP of Liberia (Constant 2000-2019). Source: Author's Computation (2020).

\section{Appendix $\mathbf{H}$}

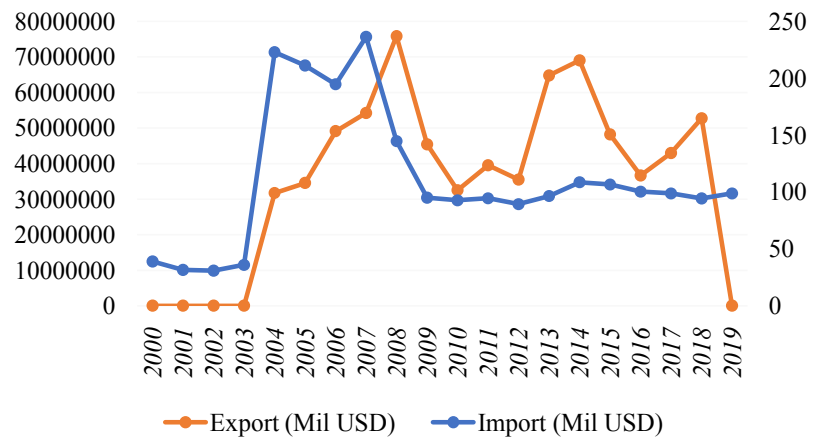

Figure S3. Export and Import Scenario of Liberia. Source: Author's Computation (2020). 